\title{
Teologi Toleransi Agama Khonghucu di Klenteng Boen Bio Surabaya
}

\author{
M Thoriqul Huda, Rikhla Sinta Ilva Sari \\ IAIN Kediri, UIN Sunan Ampel Surabaya \\ huda90.ikhac@,gmail.com, arsyaf171113@gmail.com
}

\begin{tabular}{|c|c|}
\hline \multicolumn{2}{|l|}{$\begin{array}{l}\text { Riwayat Jurnal } \\
\text { Artikel diterima: } \\
\text { Artikel direvisi: } \\
\text { Artikel disetujui: }\end{array}$} \\
\hline $\begin{array}{l}\text { Kata Kunci: } \\
\text { Toleransi } \\
\text { Agama Khonghucu } \\
\text { Klenteng Boen Bio }\end{array}$ & $\begin{array}{l}\text { Abstrak } \\
\text { Saling menghargai dan saling menghormati adalah suatu sikap } \\
\text { yang harus dimiliki oleh setiap orang untuk terwujudnya suatu } \\
\text { toleransi. Toleransi merupakan aspek terpenting dalam hidup } \\
\text { bermasyarakat. Dimana dalam hidup bermasyarakat tentu semua } \\
\text { orang menginginkan hidup yang aman, tentram, dan damai. } \\
\text { Namun, tidak dapat dipungkiri juga bahwasanya dalam } \\
\text { bermasyarakat akan banyak di jumpai perbedaan, mulai dari sifat, } \\
\text { perilaku, budaya, etnis, bahkan agama orang lain yang berbeda. } \\
\text { Perbedaan dapat membawa kita pada dua hal yang berlawanan } \\
\text { yakni permusuhan dan perdamaian. Perbedaan dapat menjadi } \\
\text { permusuhan jika diri kita tidak mampu untuk menyikapi } \\
\text { perbedaan itu sendiri, dan justru dapat menjadi perdamaian jika } \\
\text { kita dapat menerima dan menghormati perbedaan tersebut. } \\
\text { Perbedaan agama banyak menimbulkan konflik, namun dewasa } \\
\text { ini banyak orang beragama yang sadar akan perbedaan dan mulai } \\
\text { menanamkan sikap toleransi didalam dirinya. Seperti halnya } \\
\text { didalam agama Khonghucu, agama etnis Tionghoa ini juga } \\
\text { menjunjung tinggi rasa toleransi. Hal tersebut dilakukan dengan } \\
\text { alasan bahwa perbedaan merupakan hal yang pasti adanya dan } \\
\text { perbedaan seharusnya tidak untuk memecah belah melainkan } \\
\text { untuk saling melengkapi. Seperti halnya pemeluk agama } \\
\text { Khonghucu yang ada di Indonesia, mereka sangat menghargai } \\
\text { perbedaan. Etnis Tionghoa itu sadar bahwa Indonesia adalah suatu } \\
\text { Negara yang beragam, dan Indonesia lahir dari adanya perbedaan } \\
\text { tersebut. Hal itu membuktikan bahwa perbedaan membawa } \\
\text { persatuan, bukan malah membawa kehancuran. Dalam agama } \\
\text { Khonghucu juga diajarkan mengenai toleransi, yang mana hal } \\
\text { tersebut kemudian diimplikasikan dalam kehidupan } \\
\text { bermasyarakat yang penuh dengan keberagaman. Misalkan saja di } \\
\text { dalam kawasan klenteng Boen Bio di Surabaya, mereka } \\
\text { menghargai, menghormati, dan saling memahami dengan } \\
\text { masyarakat sekitar yang berbeda keyakinan dengan mereka. }\end{array}$ \\
\hline
\end{tabular}




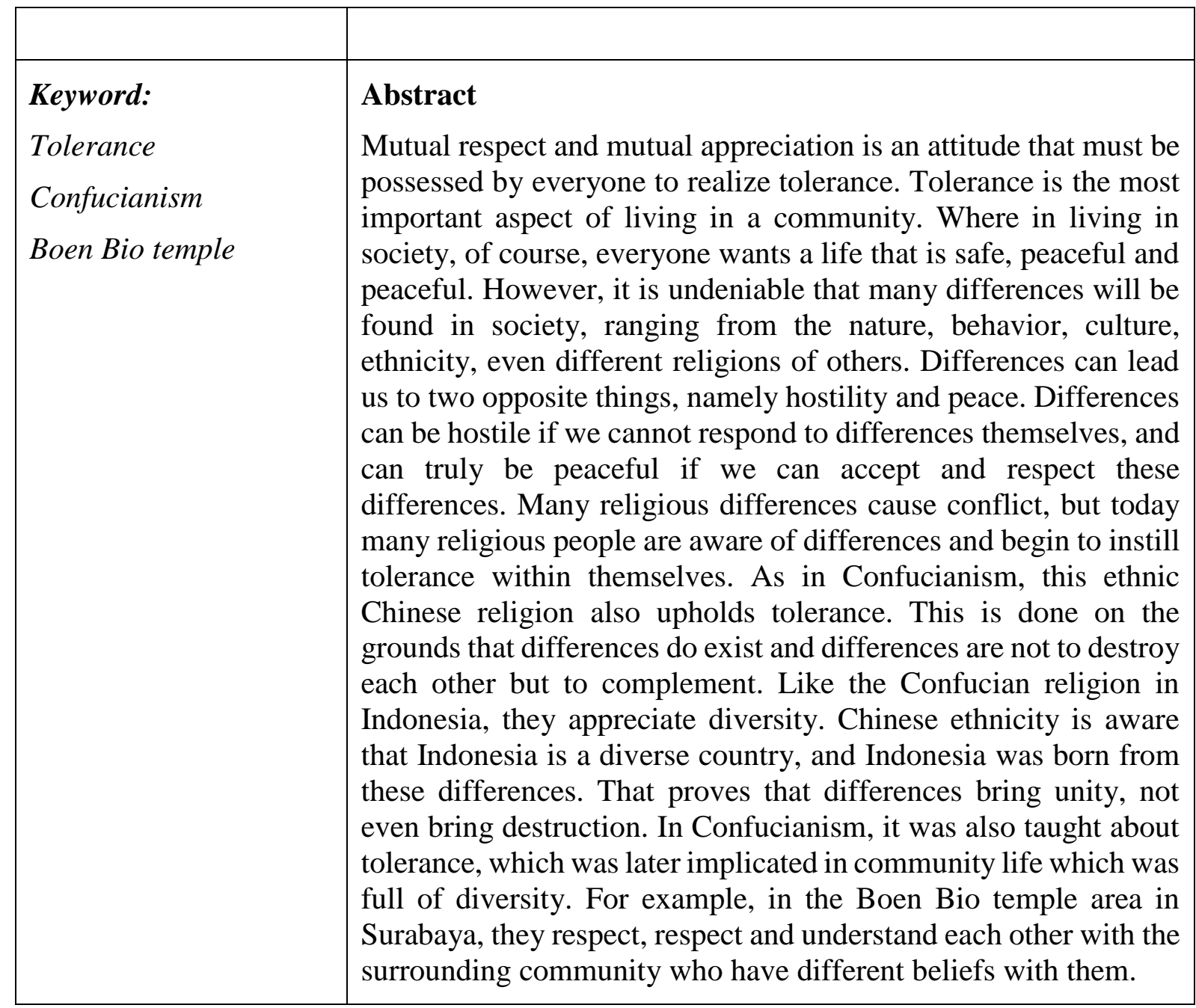

\section{Pendahuluan}

Negara Indonesia adalah Negara yang penuh dengan keberagaman. Negara Indonesia adalah contoh Negara yang dapat hidup rukun dan damai walau didalamnya terdapat banyak keragaman. Toleransi merupakan sikap yang posistif apalagi di Indonesia Negara yang berdasarkan Pancasila, yang memberi dan menjamin kebebasan bagi penduduknya untuk memeluk suatu agama dan kepercayaan yang di sukainya tanpa adanya paksaan, hal ini telah dinyatakan dalam Undang-undang Dasar 1945 pasal 29: 2, bahwa: Negara menjamin kemerdekaan tiap-tiap penduduk untuk memeluk agama masing-masing dan untuk beribadat menurut agama dan kepercayaannya (Anita Khusnun Nisa', M. Wahid Nur, 2016). Di Indonesia toleransi dijunjung tinggi, sama halnya dengan Indonesia agama Khonghucu pun juga menjunjung tinggi rasa toleransi. Sebagai agama yang pernah di anak tirikan di Negara Indonesia ini tidak menjadikan pemeluk agama Khonghucu khususnya etnis Tionghoa menjadi pemberontak di Negara ini. 
Seperti yang kita semua ketahui bahwa pada masa presiden Soeharto agama Khonghucu belum dianggap sebagai agama, hal ini dikarenakan anggapan bahwa ajaran yang dibawa oleh Nabi Khonghucu itu hanya dianggap sebagai ajaran tentang etika atau bisa dikatakan pula sebagai filsafat. Pada masa Soeharto ini perekembangan agama Khonghucu mengalami penghambatan. Pada saat itu Soeharto mengeluarkan Inpres No. 14 tahun 1967yang isinya melarang seluruh kegiatan keagamaan yang bersumber dari Tiongkok (Sulaiman, 2009: 16). Hal itu kemudian membuat etnis Tionghoa tidak memperoleh hak kebebasannya untuk menjalankan ritual keagamaan dan juga agama Khonghucu tidak memperoleh legalitas dari pemerintah pada saat itu. Namun pada masa prsiden Abdurrahman Wahid atau yang akrab disapa Gus Dur, agama Khonghucu mulai memperoleh angin segar. Dimana hal ini nampak dari pertemuan Gus Dur dengan para tokoh agama di Bali pada bulan Oktober tahu 1999, dan dalam pertemuan yang dilakukan dengan masyarakat China di Beijing pada bulan November tahun 1999. Angina segar bagi Khonghucu ini, tidak saja datang dari Gus Dur tapi juga dari ketua MPR, Amin Rais, pada saat penutupan siding umum MPR 1999, telah mengajak semua umat beragama termasuk yang beragama Khonghucu untuk berdoa atas keselamatan bangsa Indonesia (Faur Rasid, 2017: 5). Selain hal tersebut pada masa presiden Gus Dur, para pemeluk agama Khonghucu mulai memperoleh hak sipilnya dan agama Khonghucu pun menjadi agama yang legal di negara Indonesia ini. Tidak hanya itu, agama Khonghucu juga mendapat pengakuan bahwa dirinya (agama Khonghucu) merupakan bagian dari kebudayaan Indonesia.

Sebelum hal ini terjadi, agama Khonghucu sebenarnya sudah menjadi agama yang legal di Indonesia. Akan tetapi kondisi politik setelah kemerdekaan Republik Indonesiatidak menguntungkan bagi orang China serta kuatnya desakan dari pemerintah Orde Baru untuk membaurkan orang China ke dalam kelompok pribumi dan ditambah lagi dengan dikeluarkannya Surat Edaran Menteri Dalam Negeri No. 477/4054/BA.01.2/4683/95 tanggal 18 November 1978 yang menyebutkan bahwa agama yang di akui pemerintah adalah Islam, Kristen, Protestan, Katolik, Hindu, dan Budha (Faur Rasid, 2017: 17). Sehingga sejak saat itu status dari agama Khonghucu menjadi tidak jelas. Akibatnya pada saat itu banyak orang-orang pemeluk agama Khonghucu kemudian memilih untuk berpindah agama dengan masuk ke agama seperti Budha, Protestan, Katolik, dan Kristen.

Kenyataan yang ada bahwa dalam sejarah peradaban dunia pun dipenuhi dengan sejarah yang selalu menceritakan konflik yang pernah terjadi pada saat itu. Perselisihan, kesalah pahaman, bahkan peperangan yang terjadi menyangkut pada hubungan antar etnis dan juga agama yang terkadang begitu mengerikan dan tak kujung usai. Setiap orang memiliki haknya 
masing-masing untuk merasa bahwa dirinya itu lebih baik daripada orang lain (biasanya dalam hal-hal tertentu saja). Bahkan setiap bangsa juga memilii hak untuk menganggap bahwa bangsanya itu lebih baik dibandingkan bangsa yang lain, dan setiap pemeluk agama juga berhak untuk menganggap bahwa agamanya adalah yang paling baik daripada agama yang lain. Sebagai mahkhluk hidup, kita semua tentu memiliki kekurangan dan kelebihan masing-masing, dan kita tidak dapat memungkiri kedua hal tersebut, apalagi mengenai kekurangan yang dimiliki. Dimulai dari dapat menerima keadaan diri sendiri, kemudian akan dapat mewujudkan suatu sikap bijaksana dan dari kebijaksanaan tersebut kita akan memperoleh kehidupan yang harmonis pula.

Sebagai ibu kota kedua di Indonesia Surabaya banyak ditinggali oleh para etnis Tionghoa pemeluk agama Khonghucu. Dimana di kota pahlawan ini juga terdapat tempat peribadatan agama Khonghucu yang terkenal yaitu klenteng Boen Bio. Klenteng ini pertama kali dibangun didaerah Kapasan dalam pada tahun 1884 oleh Boen Tjhiang Soe (Kartono, J. Lukito, 2012: 104). Namun karena alasan yang kurang strategis kemudian dibangunlah kembali klenteng ini yang mana kita ketahui berlokasi ditepi jalan raya dengan akses yang cukup mudah. Alasan didirikannya klenteng Boen Bio ini sendiri adalah adanya inisiatif yang muncul disebabkan karena belum ada tempat ibadah untuk etnis Tionghoa sampai pada akhir abad 19 di daerah tersebut. Go Tik Lie dan Lo Toeng Siong merupakan dua orang yang memiliki inisiatif untuk mendirikan klenteng tersebut, kedua orang tersebut menyampaikan maksutnya yang ingin mendirikan rumah Ibadan dan juga melakukan perundingan Mayor The Boen Ke untuk meminta tanah dengan luas kurang lebih $500 \mathrm{~m}^{2}$ sebagai tempat didirikannya klenteng tersebut. Setelah perundingan tersebut mendapat persetujuan, kedua orang tersebut kemudian melanjutkan misinya dengan para pedagang Tionghoa untuk meminta sumbangan atau derma yang kemudian berhasil terkumpul. Untuk mendirikan klenteng mereka mendatangkan tukang dari Tiongkok dan klenteng tersebut dibangun sesuai dengan arsitektur Tiongkok, setahun kemudian yaitu pada tahun 2334 atau tahun 1883 M, pembangunan Klenteng Boen Tjiang Sor (Boen Bio) telah selesai dengan menghabiskan biaya F. 11.316.63 (Dede Burhanudin, 2017: $155)$.

Karakteristik Boen Bio jika dibandingkan lithang atau klenteng lain adalah Ia mengembangkan pemurnian Ajaran Agama Khonghucu dan menjaga atau menghindari pencampuran dengan ajaran agama lain seperti Tao dan Budha seolah-olah tidak sinkretisme (Aris Saputro, 2013: 99). Hal ini terbukti dari altar peribadatan, yang mana disana tidak terpasang patung Khonghucu, Lao Tse, dan Budha Gautama. Yang terpasang hanyalah lampu 
merah yang kecil sebagai simbol Khonghucu yang menggambarkan titik pusat sebagai focus konsentrasi kepada-Nya. Di klenteng Boen Bio ini khusus diperuntukkan kepada orang yang memeluk agama Khonghucu dalam mempelajari ajaran Khonghucu serta budaya Tiongkok yang sudah banyak ditinggalkan oleh etnis Tionghoa yang berada di Surabaya. Hal ini juga sesuai dengan namanya yaitu Boen (Wen) yang berarti kesusastraan, terpelajar atau pujangga, dan Bio (Miao) berarti kuil dan arti keseluruhan adalah kuil para terpelajar, kuil untuk mempelajari sastra atau kuil kebudayaan (Aris Saputro, 2013: 100).

Agama Khonghucu adalah agama yang berasal dari ajaran yang dibawa oleh Nabi Khonghucu. Ia tidak suka apabila dalam mengajarkan ajaranya tersebut kemudian dikaitkan dengan paham ketuhanan. Hal itu tercermin dimana Ia selalu menolak membicarakan hal-hal yang bersifat metafisika dan akhirat. Ia hanyalah seorang filosof sekuler yang mempermasalahkan moral kekuasaan dan akhlak pribadi manusia yang baik, namun dikarenakan ajaran-ajarannya yang lebih banyak mengarah pada kesusilaan dan mendekati ajaran keagamaan maka Ia sering digolongkan dan dianggap sebagai pembawa agama (Khairiah Husin, 2014: 25).

Agama Khonghucu merupakan agama yang mengajarkan perdamaian. Seperti simbol dari agama itu sendiri yakni Yin dan Yang. Menurut mereka Tuhan menciptakan kehidupan dengan dua unsur yang berbeda yang disimbolkan dalam Yin dan Yang yang berarti positif dan negative. Yin Yang itu bukanlah dikotomi tetapi sesuatu yang bersinergi, dimana dalam Yin terdapat satu titik Yang dan dalam Yang terdapat satu titik Yin, hal tersebut menjadi symbol dari perbedaan tersebut adalah untuk saling mengisi (Liem Tyong Yang, 2018). Dari dasar agama tersebut sudah diajarkan mengenai perbedaan dan juga sikap dalam menghadapi perbedaan tersebut dan hal itu adalah bentuk toleransi. Toleransi mereka terhadap orang atau kelompok yang berbeda dari mereka dan dari toleransi tersebut timbul rasa persaudaraan diantara sesama.

\section{Pembahasan}

\section{Memahami Toleransi}

Toleransi berasal dari Bahasa latin tolerantia, yang memiliki arti kelonggaran, kelembutan hati, keringanan dan kesabaran (Casram, 2016: 188). Sinonim kata dari toleransi didalam bahasa Arab ialah kata tasamuh. Tasamuh dalam bahasa Arab berarti membiarkan sesuatu untuk dapat saling mengizinkan dan saling memudahkan (Ajat Sudrajat, 2018). Dapat di pahami dari kata tasamuh tersebut dimaksudkan yang mana kita sebagai manusia jika sedang berbeda pendapat harusnya dapat saling menghargai pendapat orang lain, dimana 
masing-masing orang juga berhak untuk mengembangkan pendapatnya dan jangan saling menjatuhkan satu dengan yang lain. Toleransi dapat pula diartikan sebagai suatu sikap yang terbuka, mau menerima, saling menghargai, dan sabar. Toleransi dilakukan ditengah perbedaan atau keragaman yang ada, dimana hal tersebut dilakukan dengan harapan dapat meminimalisir terjadinya konflik ditengah perbedaan atau keragaman tersebut. Toleransi sendiri dapat juga diartikan sebagai suatu sikap yang mewujudkan adanya kerukunan antar sesama. Toleransi dapat dilakukan dalam berbagai hal, seperti salah satunya adalah toleransi dalam kehidupan beragama.

Toleransi dalam beragama merupakan suatu sikap saling menghargai antara satu dengan yang lain mengenai kepercayaan yang diyakininya dimana hal ini berkaitan dengan akidah dan ketuhanan, sikap sabar menerima orang lain dalam memilih keyakinan yang lain dan melakukan sesuatu yang lain yang dilakukan dalam menjalankan kepercayaan (beragama) sesuai dengan keyakinan yang dipilihnya. Dimana setiap individu memiliki hak dan kebebasannya untuk memilih dan menjalankan agamanya itu. Dengan ikut memberikan kebebasan dan penghormatan kepada pemeluk agama lain dalam meyakini dan menjalankan agamanya merupakan salah satu bentuk dari toleransi. Toleransi antar umat beragama merupakan penentu kerukunan dan keharmonisan kehidupan masyarakat dimana terciptanya hubungan sosial yang dinamis yang menyangkut hubungan orang perorang maupun antar kelompok masyarakat (Ika Fatmawati Faridah, 2013: 17).

Setiap agama yang ada di dunia ini lahir berbeda-beda, hal ini disebabkan karena setiap agama memiliki latar belakang budaya yang berbeda pula. Terlepas mengenai perbedaan yang ada, munculnya masing-masing agama memiliki prinsip yang sama. Kesamaan tersebut merupakan sumber dan tujuan dari agama itu sendiri yakni sama-sama bersumber dan tertuju kepada Tuhan Yang Maha Esa. Menurut Joachim Wach, merupakan tanggapan manusia beragama terhadap realitas mutlak yang di wujudkan dalam bentuk jalinan sosial antar umat satu agama maupun berbeda agama, guna membuktikan bahwa bagi mereka realitas mutlak merupakan elan vital keberagamaan manusia dalam pergaulan sosial, dan ini terdapat dalam setiap agama (Ika Fatmawati Faridah, 2013: 15).

Keyakinan adalah suatu hal yang sangat vital, apalagi berhubungan dengan keyakinan dalam beragama. Dimana setiap pemeluk agama pasti akan rela berkorban segala hal untuk membela agama yang diyakininya itu. Jika berbicara tentang perbedaan, maka segala yang ada di dunia ini tentu terdapat perbedaan. Dan jika berbicara tentang persamaan, maka segala yang berbeda itu juga pasti memiliki suatu persamaan. Namun, sikap yang salah adalah banyak orang 
yang sibuk menyamakan hal-hal yang berbeda dan juga membedakan hal-hal yang sama. Lain sisi, kita menjumpai kenyataan, dimana dalam perihal penyembahan atau mengimani, bertaqwa, dan juga bersujud kepada-Nya mempunyai cara yang tidak sama. Dari hal tersebut saja seharusnya dapat kita maklumi, apabila dalam proses penyembahan sendiri memiliki cara yang berbeda. Tentu perbedaan tersebut memiliki alasan, dimana tentu ada banyak sekali faktor yang menjadi pengaruh dari adanya perbedaan tersebut.

Toleransi sendiri juga ada di dalam ajaran agama Islam. Seperti yang dijelaskan dalam al-Qur'an dapat dengan mudah mendukung etika perbedaan dan toleransi. Al-Qur'an juga tidak hanya mengharapkan, tapi juga menerima kenyataan perbedaan dan keragaman yang ada dalam masyarakat (Indah Nurhayati, 2011: 27). Seperti firman Allah Swt., dalam surah al-Hujarat ayat 13, yang artinya: "Hai manusia, sesungguhnya Kami menciptakan kamu dari seorang lakilaki dan seorang perempuan dan menjadikan kamu berbangsa-bangsa dan bersuku-suku supaya kamu saling kenal-mengenal. Sesungguhnya orang yang paling mula diantara kamu disisi Allah ialah orang yang paling taqwa diantara kamu. Sesungguhnya Allah Maha Mengetahui lagi Maha Mengenal." Dimana sesuai dengan yang tertulis pada ayat al-Qur'an diatas bahwa Allah Swt., memang menjadikan manusia berbangsa-bangsa dan bersuku-suku adalah dengan tujuan untuk saling mengenal bukan untuk saling merasa benar. Sudah sangat jelas, bahwa Islam sangat menghargai perbedaan dan memerintahkan untuk saling mengenal dalam perbedaan itu, dan hal itu adalah bentuk dari sebuah toleransi.

Dalam memaknai toleransi tersebut terdapat dua perspektif yang berbeda tentang konsep toleransi yakni dari sisi negative dan dari sisi positif. Yang pertama, perspektif dari sisi negative yang menyatakan bahwasannya toleransi itu hanya cukup dengan memberikan syarat yakni adanya sikap membiarkan orang lain dan tidak menyakiti orang lain atau kelompok lain, baik yang berbeda maupun yang sama dengan kita. Sedagkan yang kedua, persepektif dari sisi positif yang menyatakan bahwa toleransi itu bukan hanya sekedar seperti hal yang pertama (persepktif negative) namun harus pula memberikan bantuan serta dukungan terhadap keberadaan orang lain atau kelompok lainnya.

Toleransi sendiri juga mempunyai beberapa unsur yang perlu ditekankan dalam praktiknya terhadap orang ataupun kelompok lain. Ada empat unsur yang dimaksud, yakni memberikan kebebasan atau kemerdekaan, mengakui hak setiap orang, menghormati keyakinan orang lain, dan saling mengerti. Dimana penjelasan keempat unsur-unsur tersebut ialah, yang pertama, mengenai memberikan kebebasan atau kemerdekaan. Pada hakekatnya manusia diciptakan disertai dengan kebebasan atau kemerdekaan dalam berbuat dan bertindak 
menurut dirinya sendiri sejak kelahirannya sampai ia meninggal, hal itu juga termasuk dalam kebebasan atau kemerdekaan untuk memilih dan meyakini suatu agama ataupun kepercayaan. Dimana hal tersebut tentu saja tidak dapat diwakilkan ataupun direbut oleh orang lain dengan alasan dan cara apapun itu. Hal ini disebabkan karena kebebasan atau kemerdekaan itu sendiri berasal dari Tuhan Yang Maha Esa yang berarti harus dijaga serta dilindungi dengan baik. Dimana dalam setiap negara, mengenai kebebasan atau kemerdekaan ini juga diatur dalam Undang-undang ataupun peraturan yang dibuat oleh negara. Demikian pula dalam memilih suatu agama atau keyakinan yang setiap orang berhak memilih sesuai dengan keinginannya tanpa ada paksaan dari siapapun itu. Yang kedua, mengakui hak setiap orang. Hak beragama (memeluk dan menjalankan ibadah) yang dijamin oleh konstitusi dan perundang-undangan lainnya bukanlah hak yang dapat dilaksanakan sekehendak hati, artinya ada rambu atau syaratsyarat tertentu agar pelaksanaan hak itu tidak menggangu hak orang lain, keamanan dan ketertiban masyarakat, Negara, dan bangsa; dengan kata lain ada pembatasan-pembatasan yang harus diperhatikan oleh penduduk, pembatasan tersebut ada pada Pasal 28J ayat (2) UUD 1945 jo Pasal 73 UU HAM, Pasal 28J ayat (2) menentukan bahwa dalam menjalankan hak dan kebebasannya, setiap orang wajib tunduk kepada pembatasan yang ditetapkan dengan undangundang yang dimaksud semata-mata untuk menjamin pengakuan serta penghormatan atas hak dan kebebasan orang lain dan untuk memenuhi tuntutan yang adil sesuai dengan pertimbangan moral, nilai-nilai agama, keamanan, dan ketertiban umum dalam satu masyarakat demokratis (Rini Fidiyani, 2013: 469). Setiap orang memiliki haknya masing-masing, sikap secara mental yang mengakui hak orang lain dalam menentukan sikap diri sendiri dalam berperilaku, tentu sikap dan perilaku yang dilakukan tersebut tidak sampai melanggar hak orang lain. Dimana apabila dalam menentukan sikap berperilaku sampai mengganggu hak orang lain, maka akan membuat kehidupan dalam bermasyarakat menjadi kacau. Yang ketiga, menghormati keyakinan orang lain. Keyakinan seseorang berdasarkan pada suatu keyakinan, dimana hal ini berarti keyakinan tidak dapat dipaksakan. Tidaklah benar jika terdapat seseorang atau kelompok yang dengan egois memaksakan kehendak pribadi kepada orang atau kelompok lain. Dimana pasti tidak ada orang yang mau memainkan kebenaran dengandasar bahwa keyakinan adalah urusan dan kehendak diri sendiri dan hal itu merupakan urusan dari setiap orang. Dan yang keempat, saling mengerti. Sikap saling menghormati dengan sesama manusia tidak akan terwujud apabila dalam diri manusia itu sendiri tidak ada sikap atau rasa untuk saling mengerti antara satu dengan yang lainnya. Anggapan bahwa hanya dirinya atau golongannya itu adalah yang paling benar dan membenci yang berbeda dengan diri atau golongannya merupakan salah 
satu sebab dari tidak adanya sikap saling mengerti, saling menghormati, dan saling menghargai dengan orang lain ataupun dengan perbedaan yang ada.

Dari keempat unsur yang dijelaskan diatas sudah sangat jelas diketahui bahwa dengan menghargai orang lain atau kelompok yang lain dapat mewujudkan suatu sikap toleransi. Dimana saat toleransi itu terjalin dengan baik tanpa saling merugikan antara satu orang atau kelompok yang lain, maka pada saat itulah kehidupan yang tentram, damai, dan aman dapat terwujud. Dan dengan saling mengenal satu sama lain ditengah perbedaan yang ada, juga dapat memberikan suatu kehidupan dalam bermasyarakat menjadi baik karena sudah sesuai dengan aturan dan juga norma-norma yang ada dan berlaku dalam masyarakat tersebut.

Dalam agama Khonghucu pun juga diajarkan tentang toleransi. Agama Khonghucu adalah agama yang identik dengan etika moralnya. Nabi Khongzi (Khonghucu) tidak pernah mengajarkan umatnya untuk mengungguli pihak mana pun juga, tidak ada satu ayat pun dari kitab Si Shu (Su Si) yang memerintahkan umatnya untuk berlomba-lomba menambah pengikut, terlebih dengan cara merebut umat dari agama lain, bila setiap agama ingin selalu mengungguli pihak lain, menaifkan satu sama lain dan merasa di tunjuk Tian sebagai 'agen tunggal kebenaran', maka hasilnya energi yang seharusnya digunakan untuk membina diri malah digunakan untuk saling mengalahkan, selalu siap menerkam, menjadi beringas dan kehilangan nilai luhur dari ajaran agama itu sendiri (Gunadi, Hartono, 2016: 148).

\section{Teologi Toleransi dalam Agama Khonghucu}

Setiap agama mengajarkan cinta kasih dan juga perdamaian, begitupun didalam agama Khonghucu. Ajaran untuk saling menghargai satu dengan yang lain juga diajarkan didalamnya. Seperti halnya yang tertulis dalam kitab suci agama Khonghucu yakni kitab suci Si Shu, dinyatakan dalam Lun Yu II. 14, sebagaimana yang tertulis berikut: "Seorang Jun Zi dapat rukun meski tidak dapat sama; seorang rendah budi (Xiao Ren) dapat sama meski tidak dapat rukun."( Lun Yu II, 14). Dalam ayat tersebut tertulis Jun Zi yang memiliki arti orang yang baik budi, sedangakn Xiao Ren sudah jelas memiliki arti orang yang rendah budi. Dimana dijelaskan bahwa orang yang rendah budi (Xiao Ren) atau orang yang tidak baik walaupun sama tetapi mereka (Xiao Ren) tidak dapat hidup dengan rukun. Sedangkan orang yang baik budi (Jun Zi) walaupun berbeda namun mereka (Jun Zi) dapat hidup dengan rukun. Sama yang dimaksudkan disini ialah dalam segala hal, misal saja orang yang rendah budi (Xiao Ren) itu dengan sesamanya yang seagama ataupun etnis tidak dapat hidup dengan rukun, hal ini dikarenakan bahwa mereka (Xiao Ren) memiliki rendah budi atau sama dengan memiliki perilaku atau budi 
yang tidak baik, karena itulah yang kemudian menjadikan mereka (Xiao Ren) tidak dapat hidup rukun walaupun itu dengan sesamanya, jika dengan sesamanya saja mereka (Xiao Ren) tidak dapat hidup rukun maka sudah pasti mereka tidak akan dapat hidup rukun dengan siapapun yang berbeda dengan mereka (Xiao Ren). Sedangkan dalam orang yang baik budi (Jun Zi) juga , mereka (Jun Zi) dapat hidup dengan rukun walaupun dengan yang berbeda. Karena baik budi atau sama dengan orang yang memiliki sikap, sifat, dan perilaku yang baik, maka mereka (Jun $\mathrm{Zi}$ ) akan dengan mudah hidup rukun dengan yang berbeda, mereka ( $\mathrm{Jun} \mathrm{Zi}$ ) saling menghargai dan bertoleransi dengan yang lain. Mereka (Jun Zi) memiliki pegangan yakni segala pikiran, perkatan, dan juga perbuatannya sesuai dengan firman Tuhan yang diajarkan oleh nabi Khongzu, karena pikiran, perkataan, dan perbuatan yang sesuai dengan yang diajarkan oleh nabi Khongzu maka dengan itu mereka akan menjadi orang yang baik budi (Jun Zi).

Ada pula ayat pendukung dari ayat diatas, yang dinyatakan dalam Lun Yu XII: 23, sebagaimana Yang tertulis berikut: "Seorang Jun Zi mengutamakanmkepentingan umum, bukan kelompok; seorang rendah budi (Xiao Ren) mengutamakan kelompok, bukan kepentingan umum." (Lun Yu XII, 23). Dijelaskan pula bahwa seorang yang baik budi (Jun Zi) akan lebih mengutamakan kepentingan umum daripada kelompok, dari hal itu juga dapat dijadikan sebagai suatu dasar toleransi. Dimana kepentingan umum, didalam yang umum itu tentu ada berbagai perbedaan dan mereka mau bahkan lebih mementingkan kepentingan umum itu merupakan suatu sikap yang baik. Dengan mau berbagi, memahami, dan juga mengerti dengan yang lain daripada kelompoknya merupakan suatu cerminan dari toleransi itu sendiri. Mereka yang berbudi baik (Jun Zi) tentu akan lebih mementingkan kepentingan orang lain atau umum daripada kepentingan pribadi atau kelompok, mereka akan lebih mudah berbagi karena berbudi baik (Jun Zi). Namun, berbeda dengan mereka orang-orang yang rendah budi (Xiao Ren), mereka akan lebih tidak peduli dengan kepentingan umum. Mereka cenderung sulit untuk berbagi, memahami, dan juga mengerti dengan hal lain atau orang atapun umum dikarenakan diri mereka sendiri yang rendah budi atau memiliki budi pekerti yang kurang baik. Dari kedua ayat ini dapat diketahui bahwa toleransi juga diajarkan dalam agama Khonghucu. Dalam kedua ayat tersebut dijelaskan bahwa orang yang baik budi (Jun Zi) dan orang yang rendah budi (Xiao Ren) merupakan dua gambaran dari alasan seseorang yang bertoleransi. Dimana toleransi tersebut dimulai dari diri sendiri, dari bagaimana pribadi seseorang dalam beragama. Jika seseorang berpegang teguh dan menjadikan ajaran agamanya sebagai pedoman dalam berpikir, berkata, dan berbuat maka seseorang akan dengan mudah bahkan sudah pasti bahwa orang tersebut akan dapat untuk saling menghargai, menerima, dan memahami dengan yang lain. 
Selain dua ayat diatas tersebut, ada pula ayat dalam kitab suci agama Khonghucu yang juga menjadi dasar toleransi dalam agama Khonghucu tersebut. Seperti yang dinyatakan dalam Lun Gi XV: 24, yang mana tertulis sebagai berikut: “Jangan melakukan sesuatu kepada orang lain, jika kamu tidak ingin orang lain melakukannya kepada kamu." Dalam ayat ini menjelaskan bahwa segala sesuatu yang dilakukan akan kembali kepada diri sendiri. Dimana dalam ayat itu sudah sangat jelas dikatakan, jika kita tidak ingin memperoleh perlakuan (tidak baik) dari orang lain maka kita juga jangan berperilaku (tidak baik) kepada orang lain pula. Ayat ini dijadikan sebagai suatu dasar dari ajaran dalam agama Khonghucu yang mengenai persaudaraan. Sementara itu agama Khonghucu juga mengajarkan bahwa manusia memiliki potensi untuk menjadi manusia yang baik, karena pada dasarnya manusia baik karena adanya pendidikan moral (A. Singgih Basuki, 2014: 49).

Perbedaan selalu ada, kapan pun dan dimana pun berada perbedaan itu pasti terdapat disana dan setiap manusia tidak dapat menghindari hal itu. Apabila kita salah dalam menilai dan melihat suatu perbedaan itu, maka segala perbedaan itu akan terasa bertentangan dengan kita. Hal ini dikarenakan diri kita sendiri yang tidak dapat menerima dan memahami perbedaan tersebut. Sedangkan, apabila diri kita dapat menerima dan memahami perbedaan tersebut dengan baik, maka perbedaan yang ada tersebut justru akan menjadi suatu hal sangat baik untuk kita karena sebenarnya menghadapi perbedaan itu hanya bagaimana cara kita dapat menerima dan memahami dengan baik. Mencoba menerima dan memahami yang di inginkan orang lain dan juga apa yang diri kita inginkan dari orang lain merupakan suatu hal yang tidak mudah, namun bukan berarti tidak bisa dilakukan. Dalam menerima dan memahami yang di inginkan orang lain membutuhkan suatu pengorbanan, pengorbanan tersebut terkadang tidak mudah namun harus dilakukan demi terwujudnya suatu hubungan yang baik dan harmonis. Sebagaimana yang dinyatakan dalam Lun Yu IX: 30, yang tertulis sebagai berikut: "Yang dapat diajak belajar bersama belum tentu dapat diajak bersama menempuh jalan suci (beragama), yang dapat diajak bersama menempuh jalan suci belum tentu dapat diajak bersama berteguh, dan yang dapat diajak bersama berteguh belum tentu dapat bersesuaian paham" (Lun Yu, IX, 30). Menyamakan segala perbedaan yang ada tidak harus adanya, yang mana perbedaan biarlah tetap menjadi perbedaan. Perbedaan adalah warna dalam kehidupan, dari adanya perbedaan kita menjadi belajar tentang memahami, menghargai, dan menghormati antara satu dengan yang lainnya.

Agama Khonghucu sendiri merupakan agama yang berasal dari luar Negara Indonesia, yakni dari Negara Tiongkok dengan etnis Tionghoa. Agama Khonghucu ini tidak hanya untuk 
orang-orang yang beretnis Tionghoa saja, melainkan agama ini juga bebas untuk siapa saja setiap orang yang memilih dan meyakini serta mau menjalankan ajaran dan isi dari kitab suci agama Khonghucu. Agama Khonghucu sendiri meyakini dan juga mempercayai bahwa Tuhan itu hanya satu. Dimana Tuhan dalam agama Khonghucu sendiri disebut dengan Thian. Dalam agama Khonghucu, Tuhan sendiri memiliki 5 nama atau sifat, yaitu 1) Thian yang mengandung makna Maha Besar; Yang Maha Esa; 2) Tee, mengandung makna yang maha besar yang menciptakan dan menguasai langit dan bumi; 3) Thai Iet, yang mengandung makna Tuhan Yang Maha Esa; 4) Khian, yang mengandung makna Tuhan Yang Maha Pencipta Alam Semesta; 5) Kwi Sien, yang mengandung makna Tuhan Yang Maha Roh, Tuhan daripada hokum alam, yang menjadikan hokum (Sulaiman, 2009: 55). Ajaran tentang ketuhanan inilah yang dijadikan sebagai dasar utama dalam penerapan konsep keimanan agama Khonghucu. Selain itu, didalam agama Khonghucu sendiri memiliki nabi bernama Khonghucu. Nabi Khonghucu merupakan nabi besar dalam agama Khonghucu serta seorang tokoh penyempurna ajaran para leluhur terdahulu China. Khonghucu merupakan seorang yang bermoral dan menjunjung tinggi nila-nilai moral (Gunawan Saidi, 2009: 15). Setiap agama tentu memiliki kitab suci, begitupun agama Khonghucu juga memiliki kitab suci yakni kitab Su Si. Kitab suci $\mathrm{Su} S i$ dalam agama Khonghucu merupakan pedoman hidup bagi para pemeluk agama Khonghucu.

\section{Implementasi Ajaran Toleransi di Klenteng Boen Bio Surabaya}

Agama Khonghucu di perkirakan sudah ada di Indonesia lama sebelum zaman HindiaBelanda. Hal ini dikuatkan dengan adanya beberapa peninggalan benda-benda kuno seperti halnya tembikar (kerajinan yang terbuat dari tanah liat atau bisa juga disebut dengan guci) dari Tiongkok yang ada beberapa kota di Indonesia seperti di Jawa Barat, Lampung, Batanghari, dan Kalimantan Barat. Perkembangan agama Khonghucu sendiri dimulai oleh para perantau etnis Tionghoa yang dating ke negeri Samudra Selatan, alasan utama para etnis Tionghoa merantau keluar tanah leluhurnya ialah dikarenakan pada saat itu negeri tercintanya sedang berada dalam kondisi yang kacau. Oleh karena itu kemudian etnis Tionghoa memilih untuk merantau keluar dari tanah leluhurnya yang kemudian membangun tempat beribadah yang disebut klenteng untuk tetap dapat memperoleh ketenangan batin akan leluhur dan juga atas tanah leluhur yang mereka tinggalkan yakni Tiongkok.

Etnis Tionghoa masuk ke Indonesia sebagai nelayan, petani, pedagang secara individual tanpa membuat suatu komunitas, kemudian mereka hidup berbaur dengan 
masyarakat dan budaya setempat. Agama Khonghucu mendapat sambutan yang cukup baik oleh masyarakat setempat, meskipun dalam perjalanannya dihadapkan dengan sedikit hambatan. Ajaran yang diajarkan oleh Nabi Khonghucu ini dirasa pantas untuk disebut sebagai agama, dimana dalam ajaran ini sendiri dianggap mengandung unsur-unsur ke-Tuhanan. Selain itu, ajaran ini juga mengandung beberapa syarat adanya suatu agama seperti halnya adanya kepercayaan kepada Tuhan Yang Maha Esa (Thian), memiliki Nabi (Nabi Khonghucu), Kitab suci (Kitab Su Si), dan memiliki tatanan agama serta ibadah untuk para pengikutnya.

Di Surabaya sendiri, terdapat bangunan klenteng tua yang sudah berusia lebih dari 1 abad. Klenteng tersebut bernama Boen Bio yang berada di J1. Kapasan No. 131, Kota Surabaya. Dimana nama tersebut sudah sangat terkenal dimana-mana, bukan karena sebagai klenteng tertua maupun klenteng terbesar. Klenteng Boen Bio menjadi klenteng yang terkenal dan juga istimewa dikarenakan dari awal berdirinya hingga saat ini, klenteng tersebut dibangun hanya diperuntukkan sebagai tempat Ibadah para pemeluk Agama Khonghucu saja dan itu menjadi satu-satunya tempat Ibadah Agama Khonghucu di Negara Indonesia, bahkan di Asia Tenggara. Boen Bio yang secara harfiah berarti "Kuil Sastra Budaya", Rumah Ibadah Khonghucu, biasa disebut "Litang" (= gerbang kebajikan), tercatat hanya di China, Jepang, dan Taiwan (Kusuma, 2018). Dengan alasan itulah klenteng Boen Bio Surabaya menjadi menarik untuk semua pemeluk agama Khonghucu baik dalam negeri maupun luar negeri.

Sebagai etnis pendatang, orang-orang Tionghoa sangat pandai dalam mengambil hati warga pribumi. Khususnya di klenteng Boen Bio Surabaya, mereka sadar jika mereka sebagai pendatang dengan warga pribumi itu berbeda. Namun mereka sampai saat ini dapat hidup rukun berdampingan dengan warga pribumi. Hal tersebut dikarenakan orang-orang Tionghoa ini mengaplikasikan ajaran Nabi Khonghucu dalam kehidupan mereka. Dengan mereka dapat memahami perbedaan yang ada dan saling menerima, menjadikan mereka dapat hidup rukun dengan warga pribumi. Dan hal itu merupakan bentuk dari toleransi, seperti halnya yang diajarkan dalam agama Khonghucu.

Adapun teks yang tertulis dalam kitab $\mathrm{Su}$ Si sebagaimana yang sudah dijelaskan dalam sub bab diatas mengenai toleransi. Dalam pengaplikasiannya dalam klenteng Boen Bio, para jemaat rutin melakukan bakti sosial, yakni seperti membagikan sembako dalam memperingati hari kesetiakawanan sosial dan juga pada peringatan hari persaudaraan. Dan pada saat tahun baru mereka juga membagikan sembako kepada warga yang berada disekitar klenteng Boen Bio tersebut, tanpa memandang agama dan hal tersebut dilakukan dengan tujuan untuk berbagi kebahagiaan terhadap sesama manusia. 
Selain itu wujud toleransi juga tampak pada tarian tradisional China, yaitu barongsai. Dimana tarian barongsai yang terdapat di Klenteng Boen Bio Surabaya, para anggota dari tarian tersebut tidak hanya berasal dari etnis Tionghoa atau beragama Khonghucu saja. Melainkan anggota barongsai disana juga banyak yang berasal dari etnis Jawa dan juga Madura (dua etnis yang hidup berdampingan dengan mereka) dan kemungkinan besar beragama Islam. Menurut etnis Tionghoa hal tersebut bukanlah masalah serius, karena dalam hidup perbedaan itu bukanlah hal yang serius. Karena adanya perbedaan adalah untuk saling melengkapi, seperti halnya symbol dari agama mereka yakni Yin dan Yang (Liem Tyong Yang, 2018).

Jemaat Klenteng Boen Bio juga menggunakan budaya sekitar untuk menanamkan rasa toleransi. Dimana setiap perayaan hari ulang tahun Nabi Khonghucu selalu diadakan pertunjukan Wayang Kulit dengan berbagai lakon. Dimana sudah kita ketahui bahwa wayang kulit merupakan budaya asli orang Jawa, dan dengan menggunakan budaya sekitar untuk peringatan hari tertentu dalam agama Khonghucu tentu akan membuat warga disekitar klenteng merasa senang. Karena mereka mengetahui bahwa orang Tionghoa datang tidak membahayakan mereka ataupun menghapus budaya nenek moyang mereka, melainkan orang Tionghoa datang dengan damai untuk mencari kedamaian dan kemudian berakulturasi dengan budaya setempat demi agar dapat diterima dan hidup berdampingan dengan damai. Dengan memberikan kenyamanan dan menghormati budaya sekitar, dapat menumbuhkan sikap untuk saling menghormati satu dengan yang lain dan tentu hal itu kemudian menjadikan perbedaan bukanlah penghalang dari suatu perdamaian.

Selain beberapa hal diatas, toleransi juga sudah sangat terlihat pada masa pembangunan klenteng Boen Bio itu sendiri. Dimana pada saat itu klenteng Boen Bio memperoleh banyak bantuan tidak terkecuali bantuan itu datang dari orang-orang non-Khonghucu, yang berupa materi untuk kelancaran pembangunan klenteng Boen Bio tersebut. Hal tersebut sudah sangat jelas bahwa toleransi dan juga kepedulian antar umat beragama sudah terjalin sejak saat itu. Hubungan yang seperti itu dapat terjalin dengan baik dikarenakan setiap individu mengerti dan mengetahui akan hak-hak orang lain. Dalam beragama pun hak juga harus diperoleh, karena memilih dan meyakini serta menjalankan ajaran agama yang dipeluknya itu adalah hak yang harus didapatkan oleh setiap orang yang beragama dan itu juga mendapat perlindungan hokum yang sah di Negara Indonesia ini.

Orang-orang Tionghoa juga menjunjung tinggi persatuan, dimana Indonesia ini adalah Negara yang beragam dan itulah yang membuat orang Tionghoa pemeluk agama Khonghucu ini sangat menjunjung tinggi rasa toleransi. Mereka menyadari bahwa Indonesia ada karena 
berbagai keberagaman pulau, suku, budaya, dan juga agama. Bukan Indonesia namanya jika didalamnya tidak terdapat keragaman, karena keragaman yang ada itulah lahirnya Negara Indonesia. Oleh karena, itu orang-orang Tionghoa ini merasa tidak perlu mempermasalahkan perbedaan yang ada, melainkan harus dapat berfikir bagaimana untuk dapat terus menjaga persatuan didalam perbedaan atau keragaman yang ada.

\section{Kesimpulan}

Toleransi ada dalam diri setiap orang, memiliki dasar pikiran yang positif tentang perbedaan, bahwa perbedaan merupakan suatu hal yang selalu ada didalam kehidupan ini. Perbedaan bukan suatu yang buruk, dalam perbedan tentu terdapat sisi yang positif. Dalam perbedaan itu sendiri pasti terdapat persamaan yang mana persamaan tersebut yang akan menjadikan suatu keharmonisan antar sesama. Dan jika berbicara tentang persamaan, maka segala yang berbeda itu juga pasti memiliki suatu persamaan. Namun, sikap yang salah adalah banyak orang yang sibuk menyamakan hal-hal yang berbeda dan juga membedakan hal-hal yang sama. Lain sisi, kita menjumpai kenyataan, dimana dalam perihal penyembahan atau mengimani, bertaqwa, dan juga bersujud kepada-Nya mempunyai cara yang tidak sama. Dari hal tersebut saja seharusnya dapat di maklumi, apabila dalam proses penyembahan sendiri memiliki cara yang berbeda. Tentu perbedaan tersebut memiliki alasan, dimana tentu ada banyak sekali faktor yang menjadi pengaruh dari adanya perbedaan tersebut. Menyamakan segala perbedaan yang ada tidak harus adanya, yang mana perbedaan biarlah tetap menjadi perbedaan. Perbedaan adalah warna dalam kehidupan, dari adanya perbedaan kita menjadi belajar tentang memahami, menghargai, dan menghormati antara satu dengan yang lainnya.

Orang-orang Tionghoa sangat pandai dalam mengambil hati warga pribumi. Khususnya di klenteng Boen Bio Surabaya, mereka sadar jika mereka sebagai pendatang dengan warga pribumi itu berbeda. Namun mereka sampai saat ini dapat hidup rukun berdampingan dengan warga pribumi. Hal tersebut dikarenakan orang-orang Tionghoa ini mengaplikasikan ajaran Nabi Khonghucu dalam kehidupan mereka. Dengan mereka dapat memahami perbedaan yang ada dan saling menerima, menjadikan mereka dapat hidup rukun dengan warga pribumi. Dan hal itu merupakan bentuk dari toleransi, seperti halnya yang diajarkan dalam agama Khonghucu. Orang-orang Tionghoa juga menjunjung tinggi persatuan, dimana Indonesia ini adalah Negara yang beragam dan itulah yang membuat orang Tionghoa pemeluk agama Khonghucu ini sangat menjunjung tinggi rasa toleransi. Mereka menyadari bahwa Indonesia ada karena berbagai keberagaman pulau, suku, budaya, dan juga agama. Bukan Indonesia namanya jika didalamnya tidak terdapat keragaman, karena keragaman yang ada itulah 
lahirnya Negara Indonesia. Oleh karena, itu orang-orang Tionghoa ini merasa tidak perlu mempermasalahkan perbedaan yang ada, melainkan harus dapat berfikir bagaimana untuk dapat terus menjaga persatuan didalam perbedaan atau keragaman yang ada.

\section{Daftar Pustaka}

Basuki Singgit .A. Sejarah, Etika, dan Teologi Agama Khonghucu. Yogyakarta: Suka Press 2014

Burhanudin Dede. "Nilai dan Makna Ajaran Khonghucu”. Jurnal Lektur Keagamaan. Vol. 15. No. 12017

Casram. "Membangun Sikap Toleransi Beragama dalam Masyarakat Plural". Jurnal Ilmiah Agama dan Sosial Budaya. Vol. 1. No.2. Juli 2016

Faridah Fatmawati Ika. "Toleransi Antar Umat Beragama Masyarakat Perumahan". Jurnal Komunitas. Vol. 5. No. 1. Maret 2013

Faur Rasid, Skripsi. "Gus Dur dan Agama Khonghucu di Indonesia”. Ciputat: UIN Syarif Hidayatullah 2017

Fidiyani Rini. "Keharmonisan dan Toleransi Umat Beragama di Desa Cikakak. Kec. Wangon, Kab. Banyumas". Jurnal Dinamika Hukum. Vol. 13. No. 3. September 2013

Gunadi. Hartono. "Pendidikan Agama Khonghucu dan Budi Pekerti". Jakarta: Pusat Kurikulum dan Pembukuan Balitbang Kemendikbud 2016

Husin Khairiah. Agama Khonghucu. Riau: Asa Riau. 2014

Kusuma .B. "Mengunjungi Rumah Ibadah Boen Bio Surabaya". Study Park of Confucius. September: 2013. http://www.spocjournal.com 15/12/2018 09:34 WIB

Liem Tyong Yang. Wawancara. Surabaya. 10 Desember 2018

Lukito. J. Kartono. "Studi Tentang Konsep Tatanan Arsitektur Tionghoa di Surabaya Yang dibangun Sebelum tahun 1945". Journal of Architecture and Built Environment. Vol. 39. No. 2. Desember 2012

Lun Yu. II. 14

Lun Yu. XII. 23

Lun Yu. IX. 30

Nisa' Khusnun Anita. Nur Wahid .M. "Kajian Kritis Tentang Toleransi Beragama Dalam Islam”. Al-Hikmah: Jurnal Studi Agama-agama. Vol. 2 No. 2. 2016 
Nurhayati Indah. Skripsi: "Konsep Kerukunan antar Umat Beragama (Studi Kasus tentang Perayaan Hari Besar Umat Beragama Islam dan Agama Kong Hu Chu di Kelurahan Kranggan Kecamatan Semarng Tengah Kota Semarang)". Semarang: IAIN Wali Songo. 2011

Saidi Gunawan. Skripsi,.“ Perkembangan Agama Khonghucu di Indonesia ( Study Kasus di Masyarakat Cina Penganut Agama Khonhucu di Tangerang)". Jakarta: UIN Syarif Hidayatullah. 2009

Saputro Aris. Skripsi. "Studi Pemurnian Ajaran Khonghucu di Klenteng Boen Bio Kapasan Surabaya”. Surabaya: IAIN Sunan Ampel. 2013

Sudrajat Ajat. "Agama dan Masalah Kekerasan". hal. 4. diakses dari staffnew.uny.ac.id 13/12/2018 11:28 WIB

Sulaiman. "Agama Khonghucu: Sejarah, Ajaran, dan Keorganisasiannya di Pontianak Kalimantan Barat”. Jurnal Analisa. Vol. 16. No. 01 Januari-Juni. 2009 